\title{
First illustrations of female "Neurosurgeons" in the fifteenth century by Serefeddin Sabuncuoglu
}

\author{
G. Bademci \\ Faculty of Medicine. Department of Neurosurgery. Kirikkale. Turkey.
}

\section{Summary}

Males have dominated medicine for many centuries. Females could not appear in the medical history equally till the end of the $18^{\text {th }}$ century; although they always have been in medicine as healers. It is worth mentioning that first illustrations indicating female surgeons were found in the book written in Turkish by Serefeddin Sabuncuoglu in the $15^{\text {th }}$ century; while Europe was newly waking up from its dark ages and Middle East was under the influence of strict rules of Arabic and Islamic culture. Serefeddin Sabuncuoglu (1385-1470) was the author of the first illustrated surgical textbook Cerrahiyyetu'l-Haniyye (Imperial surgery) in Turkish Literature.

Inside miniatures drawn by Serefeddin Sabuncuoglu indicated that the female surgeons, acknowledged "Tabibe", had been allowed to practice alone in Anatolia. Tabibes are illustrated in the miniatures practicing on the management of dead foetus with foetal hydrocephalus and macrocephalus which were the first clues by means of Turkish women in Neurosurgery.

KEY WORDS: Serefeddin Sabuncuoglu. Medical history. Female surgeon. Cerrahiyyetu'l-Haniyye

Primeras ilustraciones de una mujer "Neurocirujano" en el siglo XV, por Serefeddin Sabuncuoglu

\section{Resumen}

Los hombres han dominado la medicina durante muchos siglos. Las mujeres no aparecen en la historia de la medicina hasta el final del siglo XVIII, aunque siempre han estado en la medicina como curanderas. Vale la pena mencionar que las primeras ilustraciones que indican la presencia de mujeres en la cirugía se encontraron en un libro escrito en turco por Serefeddin Sabuncuoglu en el siglo XV, mientras Europa todavía

Recibido: 29-08-05. Aceptado:15-11-05 despertaba de la oscuridad y el Oriente Medio estaba bajo la influencia de las estrictas reglas de la cultura Arábiga e Islámica. Serefeddin Sabuncuoglu (13851470) fue el autor del primer texto quirúrgico ilustrado Cerrahiyyetu'l-Haniyye (Cirugía Imperial) en Literatura Turca. Las miniaturas dibujadas por Sereffeddin Sabuncuoglu indicaban que las mujeres cirujanos, conocidas como "Tabibe", estaban autorizadas para practicar sólo en Anatolia. Se ilustra, en miniaturas, cómo las Tabibes actuaban en el tratamiento de fetos muertos con hidrocefalia y macrocefalia que fueron, por supuesto, los primeros datos de mujeres turcas en la Neurocirugía.

PALABRAS CLAVE: Serefeddin Sabuncuoglu. Historia médica. Mujer cirujano. Cerrahiyyetu' l-Haniyye

"Women have made up half the human race but you could never tell that by the books that historian write"

Arthur Schlessinger, Jr., Historian

In history of medicine, one fact which remained unchanged is that the healers had always been males. Although healer women were present in ancient literature, they were mostly dealt with magical works. Till the first female doctor had graduated from medical school in the end of $18^{\text {th }}$, females could not appear in medical history ${ }^{6}$. Cerrahiyyetu'l-Haniyye is very significant from the standpoint that not only it was the first medical treatise written in old Turkish where illustrations were widely used to present techniques of surgery, but also depicting female surgeons on action in the $15^{\text {th }}$ century.

\section{Serefeddin Sabuncuoqlu and Cerrahivyetu'I-Hanivve}

Serefeddin Sabuncuoglu (1385-1470), a Turkish surgeon, lived in the $15^{\text {th }}$ century in Amasya, a small city in Central Anatolia ${ }^{5}$. Amasya was a center of culture, art and commerce during $15^{\text {th }}$ century. Serefeddin Sabuncuoglu 
lived during the most glorious time of Ottoman Empire, many scientist and artists raised in Amasya during his frametime as well as afterwords. The city also became architecturally enriched with the buildings of numerous new mosques, palaces, inns, bridges, fountains, schools and hospitals ${ }^{21}$. He worked as a physician in the Amasya Hospital for 14 years, when it was a very prestigious to hold a position as a doctor in a hospital ${ }^{20}$. Sabuncuoglu, a splendid and courageous surgeon, operated in different parts of the human body, developed numerous original techniques ${ }^{3-5,8-10,22}$. He has three scientific books and four autographs known to us. His most popular work, Cerrahiyyetu'l-Haniyye is the first book written in Turkish in his own calligraphy containing colored hand made miniatures of surgical techniques and instruments. There are three original hand-written copies of the book housed two in Istanbul ${ }^{16,17}$ and one in Paris ${ }^{18}$. Unfortunately, some parts are suspected to be missing. Cerrahiyyetu'l-Haniyye consists of three chapters (cauterization treatments, surgical procedures and fractures and dislocations) with 193 topics totaling 206 pages dealing with various interests of surgery. As a pioneer of surgery and a highly qualifying scientist, unfortunately he is not widely known in time and neglected in medical history of $15^{\text {th }}$ century. His marvellous book, Cerrahiyyetu'l-Haniyye was re-discovered in 1939 by Suheyl Unver ${ }^{19}$. In 1992, liter Uzel, a Turkish medical historian, examined three copies of the book and published them in Turkish, English and Arabic ${ }^{20}$.

All the sections of Cerrahiyyetu'l-Haniyye were reviewed and concentrated mainly Chapter II. Sections 7178 dealt with the normal and abnormal labour, delivery of the dead foetus, due to hydrocephalus and macrocephalus, and management of retained placenta. Sabuncuoglu was the first to describe the classical position for gynaecologic examination, and illustrated "tabibe" (female physician) performing surgery ${ }^{10}$. Section 76 and 77 concerning with the extraction of the dead foetus was mainly based on hook insertion for traction and decompression of the foetal head. He recommends: "...If hydrocephalus causes obstructed delivery in a dead foetus, perform foetal head decompression by means of transvaginal needle or scalpel. If the obstruction is due to a large size of foetal head other than hydrocephalus (macrocephalus), crush the foetal skull".

\section{Discussion}

Although surgical practice is well known as old as mankind, females had not been allowed to practice medicine even as a midwife, in the west for centuries ${ }^{1}$.

During the ancient civilisation periods of Egyptians, Indians, Persians and later on Greeks and Romans many historical physicians and surgeons emerged from and considered to be the "father" of medicine or surgery ${ }^{11,12}$.
As an oldest clue; name of female doctors was found on the tombs belong to the Ancient Rome ${ }^{7}$. They were doctors giving drugs and treating male and female patients both. And they could be able to treat patients without permission of the male superiors. In the period between 1273-1410, twenty-three women were permitted performing surgery by their own, in their local area in Lordship of Napoly. But the development of medicine was also affected from "the dark ages" period of Europe. The nomenclature, "the dark ages" could also explain the neglection of female physicians in between $7^{\text {th }}$ and $13^{\text {th }}$ century. Women were permitted to work only as "midwife", rather than a physician. The dominant idea was that the physiology of both gender seemed to be similar but women were lower version of the mankind. Despite of all bad influence; the extreme efforts of "wisewomen", "gentle-women", "charitable-women" kept alive "female doctors" in medicine towards $16^{\text {th }}$ and $17^{\text {th }}$ centuries while priests and male practitioners named female healers as "unwanted" even by God". Extreme efforts of women were immense, with graduation of the first female physician from Halle University at 1754. As her name was not recorded, an English lady, Elizabeth Blackwell (1821-1910) was accepted the first woman in the United States to receive a medical degree, after 29 medical schools had denied her admission because of her sex ${ }^{15}$. During the same time, Mary Edwards Walker (1832-1919) served as a surgeon with the Union Army in the Civil War. Following, restrictions on women were extremely over at the end of $19^{\text {th }}$ and the beginning of the $20^{\text {th }}$ century ${ }^{14}$.

During the dark ages period the knowledge of medicine was kept alive by Arabic culture in the East. Arabic world was productive on science; but painting, drawing, sculpture and female practicing were strictly prohibited by Islamic rules ${ }^{2,13}$. The attitudes towards women were worse in Middle East Area and in Arabic civilization which is directed on by Islamic rules. In this period, developing Ottoman Empire had very modest look of science in Anatolia; despite the period has been unjustifiably neglected or erroneously mentioned in Arabic culture. A Turkish surgeon, Serefeddin Sabuncuoglu did not hesitate to illustrate the details of obstetric and gynaecologic procedures or to depict women dealing with and performing procedures on female patients (Figure 1); while Europe and Middle East were under the influence of strict rules of religious culture. He also worked with female surgeons, while his male colleques in West reported against the female healers.

Female surgeons in Anatolia, generally practiced on some gynaecologic procedures like surgical managements of fleshy grows of clitoris in the female genitalia, unperforated female pudenda, warts and red pustules arising in the female pudenda, perforations and eruptions of uterus, abnormal labours, extractions of the abnormal foetus or placenta. One of his chapter, interestingly, difficult delivery 


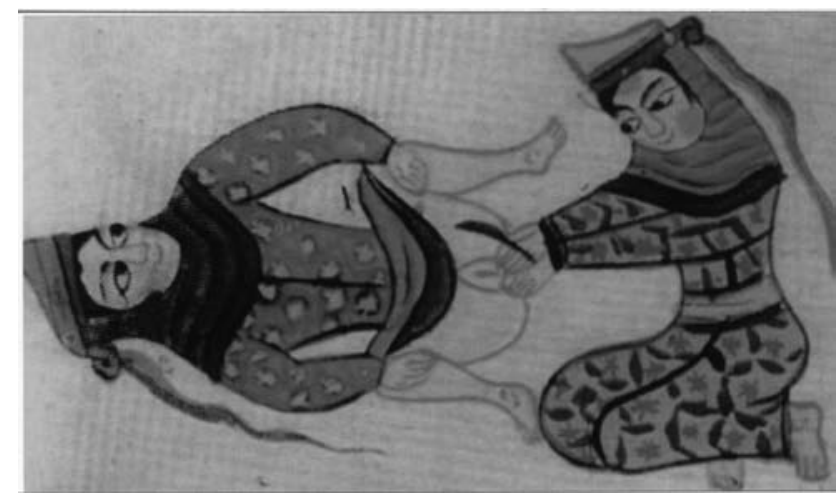

Figure 1. Illustration showing a female surgeon on a gynaecologic operation. The scalpel was clearly pictured. Reprinted with permission of the Turkish Historical Society from Uzel I.

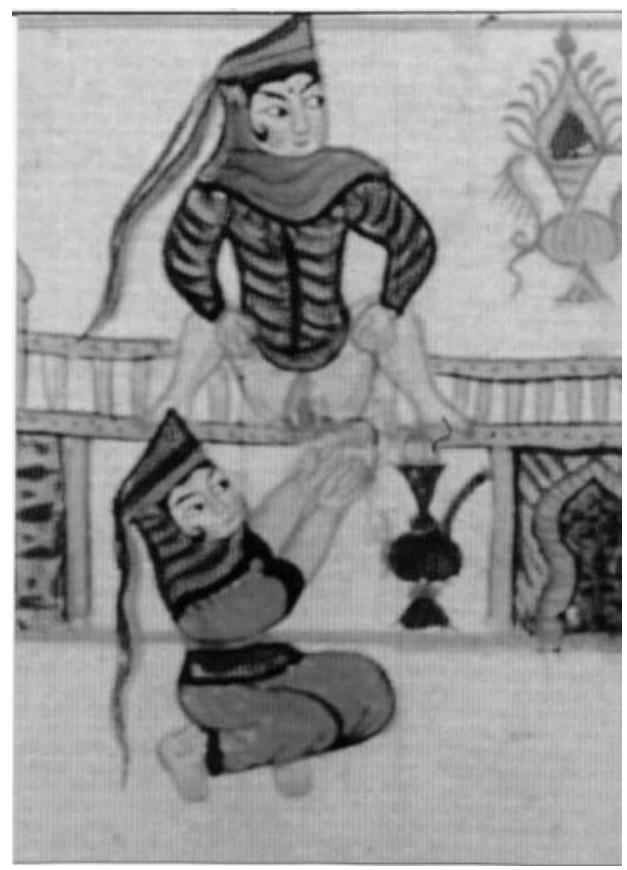

Figure 2. Illustration showing a female surgeon performing the extraction of dead foetus due to foetal hydrocephalus. Reprinted with permission of the Turkish Historical Society from Uzel I.

due to foetal hydrocephalus was described and he suggests that surgeons must be performed foetal head decompression by means of transvaginal needle or scalpel (Figure 2). If the obstruction is due to a large size of foetal head other than hydrocephalus he suggested crushing of the foetal skull. In fact, essentially miniatures of indicating female surgeons in Cerrahiyyetu'l-Haniyye can be speculated that the earliest recognition of female surgeons with pediatric neurosurgical diseases like foetal hydrocephalus and macrocephalus in the $15^{\text {th }}$ century; although arguably be organized clearly into this category.

The attitudes towards women in the medical history represent the general view of society on woman in the respected period. It is interesting that Turks had an open minded look of women, including female practitioners in the overall religion dominated time of $15^{\text {th }}$ century.

\section{References}

1. Aksoy, S.: Woman in the west in the role of healer throughtout the history. Sendrom 2001; 13: 67-69.

2. Albert, S.L., Petrucelli, R.J.: Medicine under Islam: Arabic medicine. An illustrated history. Newyork, Harry N. Abraham's, 1987.

3. Batirel, H., Yuksel, M.: Thoracic surgery techniques of Serefeddin Sabuncuoglu in the fifteenth century. Ann Thorac Surg 1997; 63: 575-577.

4. Bekraki, A., Gorkey, S., Aktan, O.: Anal surgical techniques in early Ottoman Period by Serefeddin Sabuncuoglu. World J Surg 2000; 24: 130-132.

5. Buyukunal, S.N.C., Sari, N.: Serefeddin Sabuncuoglu, the author of the earliest pediatric surgical atlas: Cerrahiye-i llhaniye. J Pediatr Surg 1991; 26: 1148-1151.

6. Coleman, V.: The story of medicine. London, Jill Norman Book, 1985, pp 385-386.

7. Conrad, L.I., Neve, M., Nutton, V., Porter, R., Wear, A.: The western medica tradition. $800 \mathrm{BC}$ to AD 1800. Cambridge, Cambridge University Press, 1985, pp 29-30 and 235235 .

8. Dogan, T., Bayramicli, M., Numanoglu, A.: Plastic surgical techniques in the fifteenth century by Serafeddin Sabuncuoglu. Plast Reconstr Surg 1997; 99: 1775-1779.

9. Elmaci, I.: Color illustrations and neurosurgical techniques of Serefeddin Sabuncuoglu in the $15^{\text {th }}$ century. Neurosurgery $2000 ; 47: 951-954$.

10. Kafali, H., Aksoy, S., Atmaca, F., San, I.: Colored illustrations of obstetrics manuplations and instrumentation techniques of a Turkish surgeon Serafeddin Sabuncuoglu in the $15^{\text {th }}$ century. Eur J Obstet Gyn RB 2002; 105: 197-202.

11. Knoeller, S.M., Seifried, C.: History of spinal surgery. Spine 2000; 25: 2838-2843.

12. Marketos, S.G., Skiadas, P.: Hippocrates: The father of spine surgery. Spine 1999; 24: 1381-1387.

13. Montagnani, C.: A pediatric surgery in Islamic medicine from the middle ages to renaissance. Prog Pediatr Surg 1986; 20-39.

14. Porter, R.: The greatist benefit to the mankind. London, Harper Collins publishers, 1997, pp 357-358.

15. Roberts, R.: American women of medicine. NJ, Berkeley heights, Enslow publishers, 2002.

16. Sabuncuoglu, S.: Cerrahiyyetu'l Haniyye. Fatih Millet Library, 1465, No:79, Istanbul.

17. Sabuncuoglu, S.: Cerrahiyyetu'l Haniyye. University of Capa, Faculty of Medicine, Library of department of His- 
tory of Medicine, Istanbul.

18. Sabuncuoglu, S.: Cerrahiyyetu'l Haniyye. Bibliothéque Nationale, Suppl Turc No: 693, 1465, Paris.

19. Unver, S.: Serefeddin Sabuncuoglu-Kitabul Cerrahiyei Ilhaniye. Istanbul, Kenan Basimevi, 1992.

20. Uzel, I.: Cerrahiyyetu'l Haniyye. Ankara, Turk Tarih Kurumu Yayinlari, 1992.

21. Uzuncarsili, I.H.: Ottoman History. Ankara, Turk Tarih Kurumu Basimevi, 1982, pp 347-350.

22.Verit, A., Aksoy, S., Kafali, H., Verit, F.: Urologic techniques of Serefeddin Sabuncuoglu in the $15^{\text {th }}$ century Ottoman Period. Urology 2003; 62: 776-778.
Acknowledgment

The authors would like to thank to Hakan Sabuncuoglu, MD. for providing us enormous references and figures from his own archive.

Bademci, G.: First illustrations of female "Neurosurgeons" in the fifteenth century by Serefeddin Sabuncuoglu. Neurocirugía 2006; 17: 162-165.

Corresponding address: Gulsah Bademci MD. Buketkent Mh. Iller Sitesi 9. BIok No: 9 06530. Cayyolu. Ankara Turkey 